\title{
Influence of Different Protected Conditions on Growth and Yield of Parthenocarpic Cucumber (Cucumis sativus) Hybrids
}

\author{
Dillip Kumar Dingal $^{1 *}$, S.S. Patil ${ }^{1}$, M.S. Birada ${ }^{2}$ and S.M. Mantur ${ }^{2}$ \\ ${ }^{1}$ Department of Horticulture, College of Agriculture, UAS Dharwad, Karnataka, India \\ ${ }^{2}$ Department of Horticulture, Hi-Tech Horticulture Unit, UAS Dharwad, Karnataka, India \\ *Corresponding author
}

\begin{tabular}{|l|}
\hline K e y w o r d s \\
Parthenocarpic cucumber, \\
Protected conditions, \\
Cucumber hybrids, \\
Protected cultivation, \\
Different conditions, \\
Shade house
\end{tabular}

\section{Introduction}

Cucumber (Cucumis sativus L.) is one of the important vegetable crops from nutritional as well as economic point of view. It is one of the most preferred vegetables grown under protected condition in the developed world. Its demand is throughout the year because of its popular use in salad dish, sandwich, pizza

\section{A B S T R A C T}

An experiment was conducted to study the influence of different protected conditions on growth and yield of parthenocarpic cucumber (Cucumis sativus L.) hybrids to standardize the suitable growing condition for protected cultivation of parthenocarpic cucumber (Cucumis sativus L.) hybrids at Hi-Tech Horticulture Unit, University of Agricultural Sciences, Dharwad during the year 2016-17. The experiment was laid out in Complete Randomized Block Design with factorial concept comprised of three protected structures, viz., Naturally Ventilated Polyhouse $\left(\mathrm{C}_{1}\right), 35$ per cent shade house $\left(\mathrm{C}_{2}\right)$ and 50 per cent shade house $\left(\mathrm{C}_{3}\right)$ and two parthenocarpic cucumber hybrids, viz., KPCH-1 $\left(\mathrm{V}_{1}\right)$ and Bahar $\left(V_{2}\right)$. The results indicated a significant difference in all the vegetative growth and yield parameters studied. The maximum vine length $(217.42 \mathrm{~cm})$, leaf area $\left(309.00 \mathrm{~cm}^{2}\right)$ and leaf area index (4.96) was recorded in polyhouse $\left(\mathrm{C}_{1}\right)$, whereas highest number of nodes per vine (37.12), relative chlorophyll content (45.56 SPAD), fruit length $(16.49 \mathrm{~cm})$, fruit weight $(158.83 \mathrm{~g})$, per cent fruit set (79.77), number of fruits per vine (30.53), yield per vine $(4.85 \mathrm{~kg})$, yield per square meter $(21.53 \mathrm{~kg})$ and yield per hectare $(206.98 \mathrm{t} / \mathrm{ha})$ were recorded in 50 per cent shade house $\left(\mathrm{C}_{3}\right)$. Among two hybrids, maximum vine length $(192.67 \mathrm{~cm})$, leaf area $\left(306.13 \mathrm{~cm}^{2}\right)$ and leaf area index (4.96), number of nodes per vine (36.33), fruit length $(17.36 \mathrm{~cm})$, fruit weight $(164.13 \mathrm{~g})$, per cent fruit set $(73.44)$, number of fruits per vine (73.83), yield per vine $(4.62 \mathrm{~kg})$, yield per square meter $(20.55 \mathrm{~kg})$ and yield per hectare $(199.91 \mathrm{t} / \mathrm{ha})$ were recorded in hybrid Bahar. Interaction between growing conditions and hybrids has no significant influence on growth and yield characters except fruit weight; maximum fruit weight was recorded by hybrid Bahar in $\mathrm{C}_{3}$. 
parthenocarpic cucumber hybrids available in India for cultivation under protected conditions. These can be grown throughout the year in protected condition with partial shade, high humidity and moderate temperature, but the research on their suitable growing condition and agro techniques are needed.

Therefore it is needed to find out the suitable growing condition which can produce high yield with comparatively low cost of cultivation. Keeping in view the above facts, the present experiment was carried out to find out the suitable protected structure for cultivation of parthenocarpic cucumber hybrids to get higher yield.

\section{Materials and Methods}

The experiment was carried out at $\mathrm{Hi}-\mathrm{Tech}$ Horticulture Unit, University of Agricultural Sciences, Dharwad. Which is located in Northern Transitional Zone (Zone No. 8) of Karnataka with latitude of $15^{\circ} 28^{\prime} 45.0^{\prime \prime}$ North, longitude of $74^{\circ} 58^{\prime} 52.2^{\prime \prime}$ East and altitude of $678 \mathrm{~m}$ above mean sea level (MSL).

The experiment was laid out in Complete Randomized Block Design with factorial concept under three growing structures (Figure 1 and 2) namely poly house $\left(\mathrm{C}_{1}\right), 35$ per cent shade house $\left(\mathrm{C}_{2}\right)$ and 50 per cent shade house $\left(\mathrm{C}_{3}\right)$ with two parthenocarpic cucumber hybrids, viz., KPCH-1( $\left.\mathrm{V}_{1}\right)$ and Bahar $\left(\mathrm{V}_{2}\right)$. In each treatment transplanting of 20 days old seedling was done with a spacing of $30 \mathrm{~cm}$ within plants and $45 \mathrm{~cm}$ between rows in paired row system.

The vegetative and yield parameters were recorded from randomly selected five tagged plants of each treatment and averaged for further analysis. All data were subjected to analysis of variance to determine main factor effect and interactions.

\section{Results and Discussion}

\section{Vegetative growth characters}

It is evident from the data (Table 1) that various types of protected structures had significant effect on vegetative growth parameters such as vine length, number of nodes per vine, leaf area, leaf area index and relative chlorophyll content (SPAD) of parthenocarpic cucumber hybrids. Significantly highest vine length $(217.42 \mathrm{~cm})$, leaf area $\left(309.00 \mathrm{~cm}^{2}\right)$ and leaf area index (4.96) was recorded in polyhouse $\left(\mathrm{C}_{1}\right)$ followed by 50 per cent shade house $\left(\mathrm{C}_{3}\right)$.

In case of poly house short wave radiation transmitted inside and long wave radiation transferred out thereby increased the inside temperature which resulted increase in vegetative growth as compared to shade house (Dwivedi and Dwivedi, 2005). The light intensity also plays an important role in vegetative growth. This higher vine length in polyhouse $\left(\mathrm{C}_{1}\right)$ was contributed by the higher internodal length which could be due to more vertical growth of the vine at low light intensity and diffused light inside the structure.

Rajasekar et al., (2013) reported that the lower temperature and light intensity caused internodal length to be higher in many vegetables including cucumber. The increased leaf area and leaf area index in polyhouse could be due to less light intensity in polyhouse which resulted in production of large sized leaves. Parashar et al., (2016) also reported that leaf area, vine length and internodal length of parthenocarpic cucumber were higher in polyhouse compared to shade house. Further the highest number of nodes (37.12) and relative chlorophyll content (45.56 SPAD) was recorded in 50 per cent shade house $\left(\mathrm{C}_{3}\right)$. Sasirekha (2016) reported that SPAD value at harvesting stage in tomato was 
higher in 50 per cent shade house compared to other growing conditions. The higher chlorophyll content contributed towards higher yield by increase in photosynthetic activity, whereas higher numbers of node per vine increase yield per vine because in parthenocarpic cucumber, every node produced one or more number of fruits.

Between hybrids, Bahar recorded significantly highest vine length $(192.67 \mathrm{~cm})$, number of nodes per vine $(36.33)$, leaf area $\left(306.13 \mathrm{~cm}^{2}\right)$ and leaf area index (4.96) whereas KPCH-1 recorded higher relative chlorophyll content (4.96 SPAD value). This might be due to the genetic character of the hybrid.

The interactions between growing conditions and hybrids not have significant influence on vegetative growth characters.

\section{Fruit characters}

Fruit characters such as fruit length and fruit weight were significantly influenced by different growing conditions. Results (Table 2) revealed that significantly higher individual fruit length $(16.49 \mathrm{~cm})$ and fruit weight (158.83 g) was recorded under 50 per cent shade house $\left(\mathrm{C}_{3}\right)$, whereas the fruit diameter has not significantly influenced by different growing conditions. This increased fruit length and weight might be due to the higher rate of photosynthesis and accumulation of food materials in fruit resulted from moderate light intensity and temperature under 50 per cent shade. Similar results were obtained by Ho (1995) in tomato. Rylski and Spigelman (1986) reported that 47 per cent shading recorded large sized fruit and thick pericarp in capsicum.

Table.1 Vegetative growth characters influenced by different growing conditions and hybrids of parthenocarpic cucumber

\begin{tabular}{|c|c|c|c|c|c|}
\hline factors & $\begin{array}{l}\text { Vine } \\
\text { length } \\
\text { (cm) }\end{array}$ & $\begin{array}{c}\text { Number of } \\
\text { nodes }\end{array}$ & $\begin{array}{l}\text { Leaf } \\
\text { area } \\
\left(\mathrm{cm}^{2}\right)\end{array}$ & $\begin{array}{l}\text { Leaf } \\
\text { area } \\
\text { index }\end{array}$ & $\begin{array}{c}\text { Chlorophyll } \\
\text { content } \\
\text { (SPAD) }\end{array}$ \\
\hline \multicolumn{6}{|l|}{ Growing conditions $(\mathrm{C})$} \\
\hline Polyhouse $\left(\mathrm{C}_{1}\right)$ & 217.42 & 36.04 & 309.00 & 4.96 & 39.18 \\
\hline 35 per cent shadehouse $\left(C_{2}\right)$ & 147.17 & 34.09 & 258.87 & 3.93 & 40.87 \\
\hline 50 per cent shadehouse $\left(C_{3}\right)$ & 176.50 & 37.12 & 281.03 & 4.65 & 45.56 \\
\hline S. Em. \pm & 0.664 & 0.085 & 1.079 & 0.021 & 0.139 \\
\hline C. D. at $5 \%$ & 1.946 & 0.249 & 3.164 & 0.062 & 0.406 \\
\hline \multicolumn{6}{|l|}{ Hybrids (V) } \\
\hline $\mathrm{KPCH}-1\left(\mathrm{~V}_{1}\right)$ & 168.06 & 35.18 & 259.80 & 4.07 & 42.79 \\
\hline Bahar $\left(\mathbf{V}_{2}\right)$ & 192.67 & 36.33 & 306.13 & 4.96 & 40.95 \\
\hline S. Em. \pm & 0.442 & 0.057 & 0.719 & 0.014 & 0.095 \\
\hline C. D. at $5 \%$ & 1.297 & 0.166 & 2.109 & 0.041 & 0.271 \\
\hline \multicolumn{6}{|l|}{ Interactions } \\
\hline $\mathrm{C}_{1} \mathrm{~V}_{1}$ & 202.00 & 35.58 & 275.83 & 4.36 & 40.51 \\
\hline $\mathrm{C}_{1} \mathrm{~V}_{2}$ & 232.83 & 36.51 & 242.17 & 5.56 & 37.86 \\
\hline $\mathrm{C}_{2} \mathrm{~V}_{1}$ & 139.50 & 33.55 & 246.13 & 3.68 & 41.70 \\
\hline $\mathrm{C}_{2} \mathrm{~V}_{2}$ & 154.83 & 34.63 & 271.60 & 4.19 & 40.04 \\
\hline $\mathrm{C}_{3} \mathrm{~V}_{1}$ & 162.67 & 36.41 & 257.43 & 4.16 & 46.17 \\
\hline $\mathrm{C}_{3} \mathrm{~V}_{2}$ & 190.33 & 37.84 & 304.63 & 5.13 & 44.95 \\
\hline S. Em. \pm & 1.327 & 0.170 & 4.315 & 0.085 & 0.277 \\
\hline C. D. at $5 \%$ & NS & NS & NS & NS & NS \\
\hline
\end{tabular}


Table.2 Flowering and fruit characters influenced by different growing conditions and hybrids of parthenocarpic cucumber

\begin{tabular}{|c|c|c|c|}
\hline Factors & Fruit length $(\mathrm{cm})$ & Fruit diameter $(\mathrm{cm})$ & Fruit weight (g) \\
\hline \multicolumn{4}{|l|}{ Growing conditions (C) } \\
\hline Polyhouse $\left(\mathrm{C}_{1}\right)$ & 15.82 & 3.49 & 151.00 \\
\hline 35 per cent shadehouse $\left(C_{2}\right)$ & 15.46 & 3.47 & 152.00 \\
\hline 50 per cent shadehouse $\left(C_{3}\right)$ & 16.49 & 3.42 & 158.83 \\
\hline S. Em. \pm & 0.041 & 0.010 & 0.287 \\
\hline C. D. at $5 \%$ & 0.121 & NS & 0.840 \\
\hline \multicolumn{4}{|l|}{ Hybrids (V) } \\
\hline KРCH-1 $\left(\mathrm{V}_{1}\right)$ & 14.49 & 3.51 & 143.76 \\
\hline $\operatorname{Bahar}\left(\mathbf{V}_{2}\right)$ & 17.36 & 3.40 & 164.13 \\
\hline S. Em. \pm & 0.027 & 0.010 & 0.191 \\
\hline C. D. at $5 \%$ & 0.081 & NS & 0.560 \\
\hline \multicolumn{4}{|l|}{ Interactions } \\
\hline$C_{1} V_{1}$ & 13.95 & 3.61 & 140.58 \\
\hline $\mathrm{C}_{1} \mathrm{~V}_{2}$ & 17.70 & 3.37 & 161.42 \\
\hline $\mathrm{C}_{2} \mathrm{~V}_{1}$ & 14.48 & 3.50 & 139.62 \\
\hline $\mathrm{C}_{2} \mathrm{~V}_{2}$ & 16.43 & 3.43 & 164.38 \\
\hline $\mathrm{C}_{3} \mathrm{~V}_{1}$ & 15.04 & 3.42 & 151.07 \\
\hline $\mathrm{C}_{3} \mathrm{~V}_{2}$ & 17.49 & 3.42 & 166.60 \\
\hline S. Em. \pm & 0.082 & 0.020 & 0.573 \\
\hline C. D. at $5 \%$ & NS & NS & 1.681 \\
\hline
\end{tabular}

Table.3 Yield and yield attributing characters influenced by different growing conditions and hybrids of parthenocarpic cucumber

\begin{tabular}{|c|c|c|c|c|c|}
\hline Treatment & $\begin{array}{c}\text { Per cent } \\
\text { fruit set }(\%)\end{array}$ & $\begin{array}{c}\text { Fruits } \\
\text { per vine }\end{array}$ & $\begin{array}{l}\text { Yield per } \\
\text { vine }(\mathrm{kg})\end{array}$ & $\begin{array}{l}\text { Yield per square } \\
\text { meter (kg) }\end{array}$ & $\begin{array}{l}\text { Yield per } \\
\text { hectare }(t)\end{array}$ \\
\hline \multicolumn{6}{|l|}{ Growing conditions $(\mathrm{C})$} \\
\hline Polyhouse $\left(\mathrm{C}_{1}\right)$ & 64.79 & 23.43 & 3.56 & 15.81 & 158.13 \\
\hline 35 per cent shadehouse $\left(C_{2}\right)$ & 69.71 & 25.96 & 4.02 & 17.82 & 178.23 \\
\hline 50 per cent shadehouse $\left(C_{3}\right)$ & 79.77 & 30.53 & 4.85 & 21.53 & 206.98 \\
\hline S. Em. \pm & 0.010 & 0.154 & 0.031 & 0.138 & 2.045 \\
\hline C. D. at $5 \%$ & 0.295 & 0.451 & 0.091 & 0.405 & 5.999 \\
\hline \multicolumn{6}{|l|}{ Hybrids (V) } \\
\hline KРCH-1 $\left(V_{1}\right)$ & 69.52 & 25.43 & 3.66 & 16.23 & 162.31 \\
\hline Bahar $\left(V_{2}\right)$ & 73.44 & 27.83 & 4.62 & 20.55 & 199.91 \\
\hline S. Em. \pm & 0.067 & 0.102 & 0.021 & 0.092 & 1.364 \\
\hline C. D. at $5 \%$ & 0.197 & 0.300 & 0.061 & 0.027 & 3.999 \\
\hline \multicolumn{6}{|l|}{ Interactions } \\
\hline$C_{1} V_{1}$ & 62.85 & 21.90 & 3.08 & 13.70 & 137.02 \\
\hline$C_{1} V_{2}$ & 67.09 & 24.95 & 4.03 & 17.92 & 179.23 \\
\hline $\mathrm{C}_{2} \mathrm{~V}_{1}$ & 67.99 & 24.87 & 3.45 & 15.29 & 152.90 \\
\hline$C_{2} V_{2}$ & 71.42 & 27.05 & 4.58 & 20.36 & 203.55 \\
\hline $\mathrm{C}_{3} \mathrm{~V}_{1}$ & 77.72 & 29.52 & 4.43 & 19.70 & 179.02 \\
\hline$C_{3} V_{2}$ & 81.81 & 31.55 & 5.26 & 23.36 & 216.93 \\
\hline S. Em. \pm & 0.201 & 0.307 & 0.062 & 0.276 & 4.091 \\
\hline C. D. at $5 \%$ & NS & NS & NS & NS & NS \\
\hline
\end{tabular}


Fig.1 Parthenocarpic cucumber growing under different protected conditions; A: in polyhouse $\left(\mathrm{C}_{1}\right), \mathrm{B}$ : in $35 \%$ shadehouse $\left(\mathrm{C}_{2}\right), \mathrm{C}$ : in $50 \%$ shadehouse $\left(\mathrm{C}_{3}\right)$

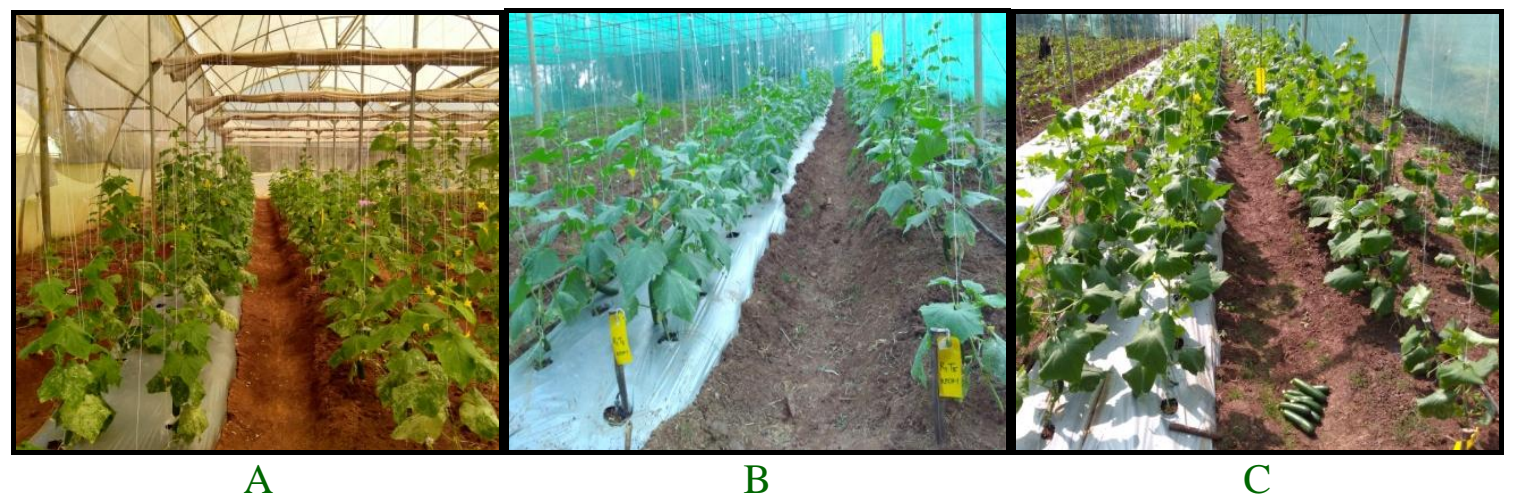

Fig.2 Fruit bearing character of two parthenocarpic cucumber hybrids; A: KPCH-1, B: Bahar

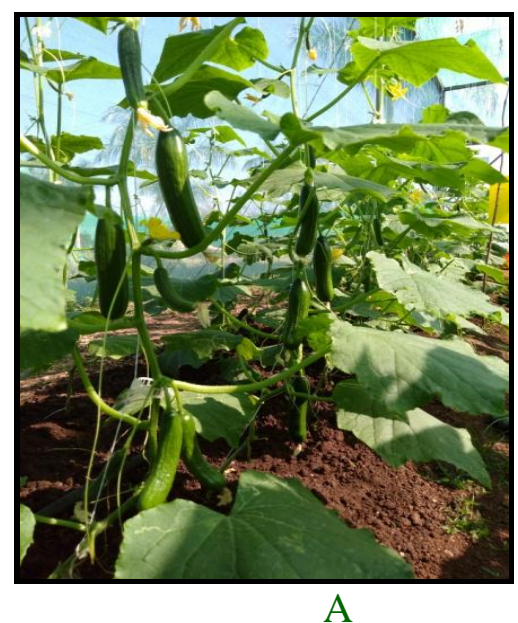

A

Between hybrids, significantly higher fruit length $(17.36 \mathrm{~cm})$ and fruit weight $(164.13 \mathrm{~g})$ was observed in Bahar whereas fruit diameter was not significantly differed between hybrids. It might be due to genetic makeup of the hybrid. Regarding interaction between growing conditions and hybrids, significantly highest fruit weight (166.60 g) was recorded in hybrid Bahar under $C_{3}$, followed by Bahar under $C_{2}$. This increase in fruit weight might be due to the synergistic effect of growing condition and hybrid which directly contributed towards the increase in fruit weight which in turn increase in yield. Fruit length and diameter have not significantly influenced by the interaction between growing conditions and hybrids.

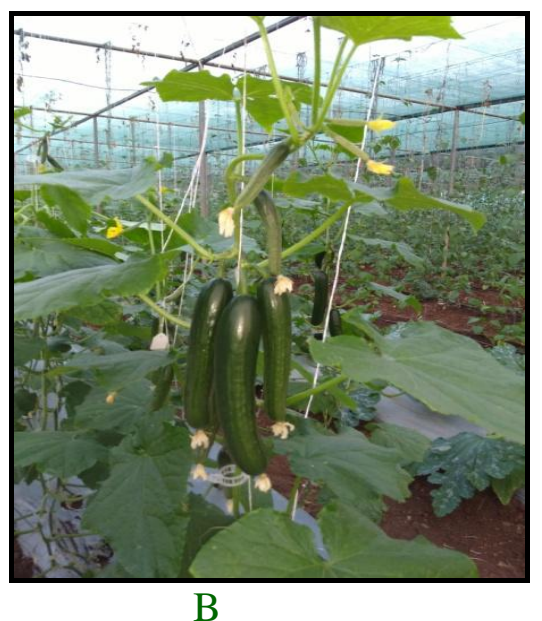

\section{Yield and yield attributing characters}

The results (Table 3) showed that significantly higher yield per vine $(4.85 \mathrm{~kg})$, yield per meter square $(21.53 \mathrm{~kg})$ and yield per hectare $(206.98$ t) was obtained from parthenocarpic cucumber grown under 50 per cent shade house $\left(\mathrm{C}_{3}\right)$, whereas the yield was significantly lower in cucumber grown under polyhouse $\left(\mathrm{C}_{1}\right)$. The higher yield under shade 50 per cent shade house could be attributed by better performance of crop with respect to various yield contributing characters such as per cent fruit set $(79.77 \%)$ and number of fruits per vine (30.53) in polyhouse. This might be due to the shade house with 50 per cent shade provide optimum light intensity, relative humidity and 
temperature which produce more number of node, higher photosynthetic rate provide the synthesis of higher amount of growth regulator like auxins such as NAA and IAA which in turn higher per cent fruit set and number of fruits per vine in parthenocarpic cucumber (Guo et al., 2010). This clearly indicated that shade house with 50 per cent shade net was suitable for getting higher yield of parthenocarpic cucumber. Rajasekar et al., (2013) also reported that in many vegetables including cucumber, increase in shade level up to 50 per cent, consequently increases the yield however further increase in shade level adversely affect the yield.

Hybrid Bahar recorded significantly higher yield per vine $(4.62 \mathrm{~kg}$ ), yield per square meter $(20.55 \mathrm{~kg})$ and yield per hectare $(199.91 \mathrm{t})$ which is contributed by higher per cent fruit set (73.44 \%), number of fruits per vine (27.83) and fruit weight (164.13 g) compared with KPCH-1. This might be due to its genetic character and suitability of this hybrids in protected condition in this climate. Interactions between growing conditions and hybrids do not have significant influence on yield and yield attributes.

On the basis of results obtained in present investigation entitled, "Influence of different protected conditions on growth and yield of parthenocarpic cucumber (Cucumis sativus L.) hybrids", it can be concluded that during winter season out of the three protected structures, viz., poly house, 35 per cent shade house and 50 per cent shade house and hybrids of parthenocarpic cucumber studied in the present experiment, 50 per cent shade house responded better in terms of yield and yield attributes. With respect to the hybrids, Bahar recorded maximum yield.

\section{References}

Dwivedi, P. and Dwivedi, R. S., eds. 2005. Physiology of abiotic stress in plants. Agrobios Publication, Jodhpur, Pp. 35-78.

Guo, S., Zheng Y., Joung, J. G., Liu, S., Zhang, Z., Crasta, O. R., Sobral, B. W. X. Y., Huang, S. and Fei, Z. 2010. Transcriptome sequencing and comparative analysis of cucumber flowers with different sex types. BMC Genomics, 11,384

Ho, L. C. 1995. Carbon partitioning and metabolism in relation to plant growth and fruit production in tomato. Acta Hort. 412, 396-409

Parashar, A., Yadav, P. K., Singh, R. S. and Shukla, A. K. 2016. Effect of different protected structures on vegetative and yield attributes of cucumber under arid conditions of Rajasthan. Prog. Hort. 48(1): 78-82

Rajasekar, M., Arumugam, T. and Ramesh Kumar, S. 2013. Influence of weather and growing environment on vegetable growth and yield. J. Hortic. For., 5(10): 160-167

Rylski, I. and Spigelman, M. 1986. Effect of shading on plant development, yield and fruit quality of sweet pepper grown under conditions of high temperature and radiation. Sci. Hortic. 29(1\&2): 31-35

Sasirekha, M. 2016. Physiological responses of tomato cultivar (Solanum lcopersicum L.) grown under different protected conditions. M. Sc. (Agri.) Thesis, Univ. Agric. Sci., Dharwad, Karnataka (India).

\section{How to cite this article:}

Dillip Kumar Dingal, S.S. Patil, M.S. Birada and Mantur, S.M. 2018. Influence of Different Protected Conditions on Growth and Yield of Parthenocarpic Cucumber (Cucumis sativus) Hybrids. Int.J.Curr.Microbiol.App.Sci. 7(05): 1619-1624. doi: https://doi.org/10.20546/ijcmas.2018.705.191 